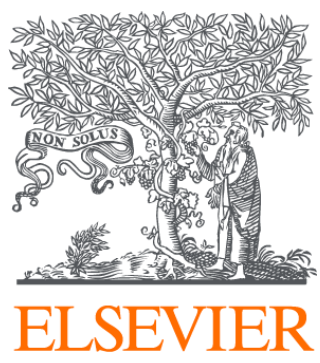

Since January 2020 Elsevier has created a COVID-19 resource centre with free information in English and Mandarin on the novel coronavirus COVID-

19. The COVID-19 resource centre is hosted on Elsevier Connect, the company's public news and information website.

Elsevier hereby grants permission to make all its COVID-19-related research that is available on the COVID-19 resource centre - including this research content - immediately available in PubMed Central and other publicly funded repositories, such as the WHO COVID database with rights for unrestricted research re-use and analyses in any form or by any means with acknowledgement of the original source. These permissions are granted for free by Elsevier for as long as the COVID-19 resource centre remains active. 


\title{
SELCO-Ecopurin ${ }^{\circledR}$ pig slurry treatment system
}

\author{
Jesus Martinez-Almela *, Jorge Manuel Barrera \\ SELCO MC, S.L. Advanced Engineering Services, Animal Residual Technologies, Pza. Tetuán, 16, E12001 Castellón, Spain
}

Received 14 May 2003; received in revised form 18 November 2003

Available online 2 July 2004

\begin{abstract}
As the practice of intensive animal production increases, there is a need for affordable treatment technologies that can help manage the large amounts of manure generated. Our approach has been to develop an efficient liquid-solid separation module using polymer technology and integrate this separation module into systems of treatment technologies for both the separated liquid and solids. We describe the progress that has been made in management techniques and new technological alternatives for manure treatment and generation of value added by-products based on the SELCO-Ecopurin ${ }^{\circledast}$ separation technology and experiences during the last five years in 12 livestock farms in Spain, Italy and the USA. High recovery of solids $(>90 \%)$ makes the use of advanced purification of the liquid a more economical alternative. The liquid can be further treated to reduce $\mathrm{N}$ and $\mathrm{P}$ and produce effluents virtually free of these nutrients. Production of methane and energy was affected by solids concentration; the anaerobic process was optimised with polymer application rate of $120 \mathrm{ppm}$ during separation and a solids content of $13 \%$.
\end{abstract}

(c) 2004 Elsevier Ltd. All rights reserved.

Keywords: Liquid manure treatment; Ionic transfer; Polymers; Ecopurin technology; Nitrification-denitrification; Phosphorus; Compost; Biogas

\section{Introduction}

A proper approach to animal manure must necessarily involve effective treatments that are both economically feasible to sustain the production business and also beneficial for the ecosystem. Ecosystem benefits include stabilization and sequestration of carbon, elimination of nitrogen and sulphur forms of harmful gaseous emissions, and restoration and enhancement of soil productivity. Furthermore, the new European directives indicate that the treatment should also consider biosecurity, health and environmental standards. These standards, applicable both to the treatment technology and the final by-product, are essential for maintaining and improving animal productivity (De la Torre et al., 2001).

Modern animal production is an extremely sophisticated business, and the management, treatment purification and valorization appreciation of its by products should also be one. As the practice of intensive animal production increases, there is an urgent need for efficient

\footnotetext{
${ }^{*}$ Corresponding author. Tel.: +34-964-254-443; fax: +34-964-256512.

E-mail address: info@selco.net (J. Martinez-Almela).

$U R L:$ http://www.selco.net
}

and affordable treatment alternatives for handling excess nutrients and associated problems with intensive production such as deterioration of water quality and nuisance odors.

It is obvious that, in order to significantly improve swine manure management, we need technologies that can achieve effective separation of solids from liquids. One such technology is ionic transfer using polymers where fine particulates typical of liquid manure are flocculated, reaching separation efficiencies $>90 \%$ (Martinez-Almela et al., 2001a). This high recovery of solids not only makes the use of advanced purification of the liquid a more economical alternative, but also increases the amount of materials available for the solids processing operation, which generates a flow of income (Vanotti and Hunt, 2001).

The evolutionary tendencies of these new treatments aiming to generate value-added products with environmental and economic efficiency criteria, are shown in Fig. 1. The diagram shows some of the treatments available for the solids and the liquid effluent after liquid-solid separation. Their unique combination and application will depend on the specific needs of a particular production unit such as nutrient management plans, odor control, or economic goals. 


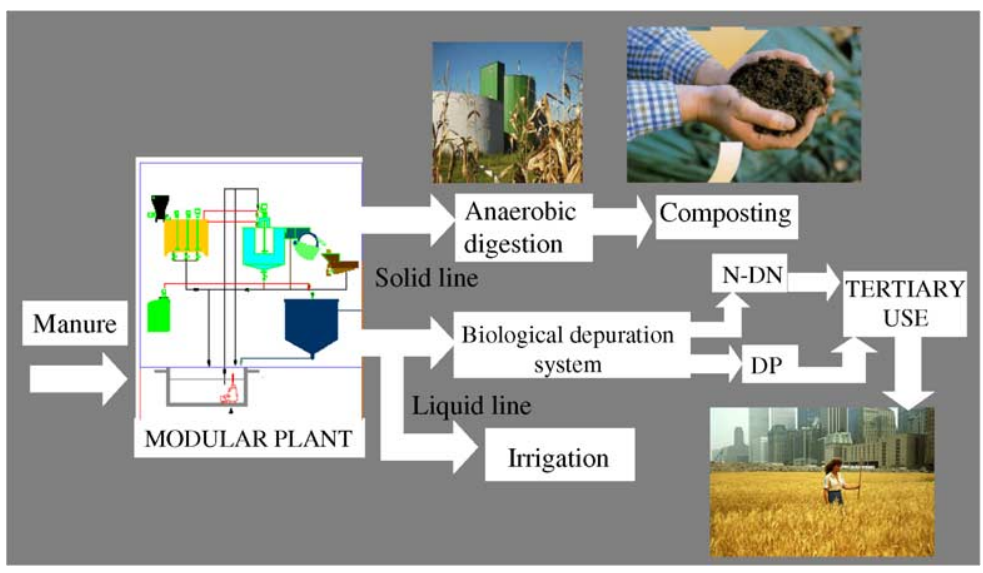

Fig. 1. View of an innovative and sustainable treatment system for animal manure.

The objective of this paper is to describe the progress that has been made in management techniques and new technological alternatives for manure treatment and generation of value added by-products based on the SELCO-Ecopurin ${ }^{\circledR}$ separation technology and experiences during the last five years in 12 livestock farms in Spain, Italy and the USA.

\section{Optimised separation of solid-liquid}

The SELCO-Ecopurin ${ }^{\circledR}$ process uses polyacrylamide (PAM) polymer and was designed to enhance solids removal from liquid manure. Separated solids can be transported off-farm and stabilized and marketed as an added value product or processed using anaerobic digestion, biogas generation and thermo-electrical cogeneration. The Ecopurin main module consists of (1) a polymer mixing section where dry polymer is activated with water; (2) the ionic transfer reactor main module where polymer is mixed with wastewater; (3) a rotating screen with $0.2 \mathrm{~mm}$ openings to separate the flocculated solids; (4) a filter press to further dewater the manure; and (5) a small dissolved air flotation unit to further separate residual solids in the liquid stream before exiting to the water treatment section. Solids skimmed from the DAF unit are returned to the mixing tank of subsequent separation (Fig. 2).

The results obtained in separation process by means of polymer technology indicate that this type of treatment is not only highly efficient in the separation of total suspended solids (TSS) and organic nutrients liquid swine manure, but also requires a very low chemical dosage. Typical polymer rate for manures containing $1-$ $1.5 \%$ TSS is about $100-120 \mathrm{mg} / \mathrm{l}$. Average separation performance obtained in full-scale on-farm plants in Europe (Table 1) was $84-95 \%$ for TSS and $63-97 \%$ for BOD. By capturing the suspended particles, most of the

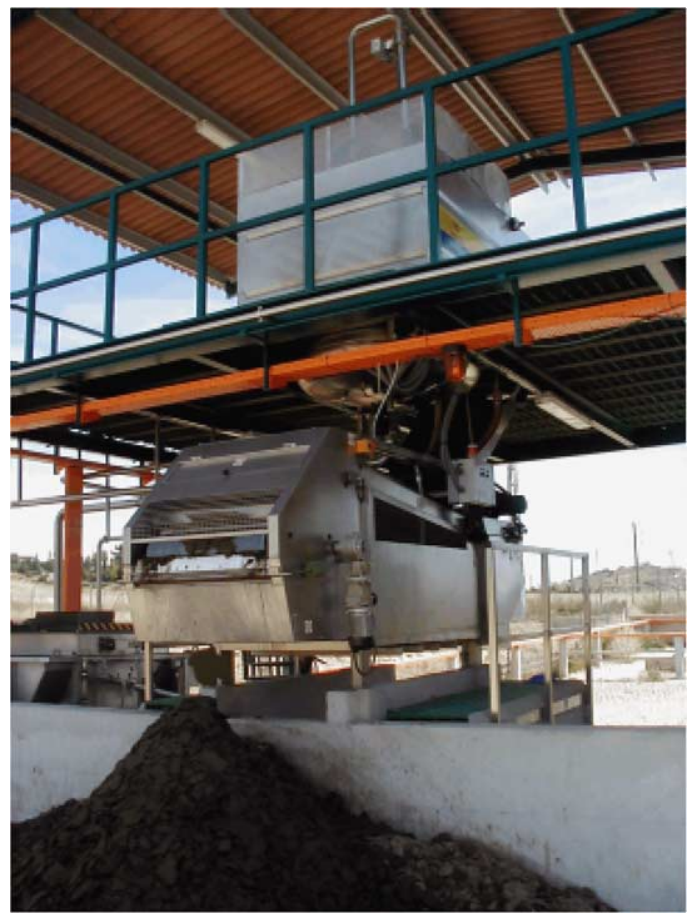

Fig. 2. View of Ecopurin separation module installed in at the University of Murcia's Veterinary School in Spain. Main reactor is in second floor, filter press is in foreground, and DAF is on the left.

volatile organic compounds which require oxygen are also removed from the liquid line. Instead of decomposing the organic compounds, the oxygen from subsequent aeration treatment after the separation of the solids is used efficiently to convert ammonia in the nitrification process.

The concentration of nutrients in the purified effluent also drops considerably, the phosphorus reduction capacity obtained was $71-89 \%$ and the TKN was 29 $58 \%$. Given that more phosphorus is removed in comparison with the nitrogen, the N/P ratio of the treated liquid effluent is improved. This higher capacity for 
Table 1

Average treatment performance of solid-liquid separation process using polymer and Ecopurin module in various pig farms in Europe (4000-8000 pigs/farm) [one year data (2002)]

\begin{tabular}{|c|c|c|c|c|}
\hline $\begin{array}{l}\text { Plant } \\
\text { location }\end{array}$ & Parameter & $\begin{array}{l}\text { Influent } \\
\text { concentra- } \\
\text { tion }(\mathrm{mg} / \mathrm{l})\end{array}$ & $\begin{array}{l}\text { Effluent } \\
\text { concentra- } \\
\text { tion }(\mathrm{mg} / \mathrm{l})\end{array}$ & $\begin{array}{l}\text { Reduction } \\
\text { main } \\
\text { module } \\
(\%)\end{array}$ \\
\hline \multirow{6}{*}{$\begin{array}{l}\text { ITALY } \\
\text { (Modena) }\end{array}$} & COD & 21,633 & 3390 & 84.33 \\
\hline & BOD5 & 10,200 & 1550 & 84.8 \\
\hline & TSS & 8567 & 427 & 95.02 \\
\hline & TKN & 2365 & 986 & 58.3 \\
\hline & $\mathrm{NH}_{4}^{+}$ & 2066 & 1091 & 47.19 \\
\hline & $\mathrm{TP}$ & 585 & 63 & 89.12 \\
\hline \multirow{6}{*}{$\begin{array}{l}\text { SPAIN } \\
\quad \text { (Barcelona) }\end{array}$} & COD & 58,137 & 21,520 & 62.98 \\
\hline & BOD5 & 12,000 & 4400 & 63.33 \\
\hline & TSS & 61,843 & 10,166 & 83.56 \\
\hline & TKN & 5469 & 2905 & 53.12 \\
\hline & $\mathrm{NH}_{4}^{+}$ & 3368 & 2726 & 19.06 \\
\hline & $\mathrm{TP}$ & 1103 & 151 & 86.31 \\
\hline \multirow{6}{*}{$\begin{array}{l}\text { SPAIN } \\
\text { (Murcia) }\end{array}$} & COD & 17,533 & 4681 & 73.30 \\
\hline & BOD5 & 7200 & 922 & 87.19 \\
\hline & TSS & 10,499 & 1105 & 89.48 \\
\hline & TKN & 1082 & 770 & 28.84 \\
\hline & $\mathrm{NH}_{4}^{+}$ & 952 & 751 & 21.11 \\
\hline & $\mathrm{TP}$ & 255 & 72 & 71.76 \\
\hline \multirow{6}{*}{$\begin{array}{l}\text { USA } \\
\text { (Goshen) }\end{array}$} & COD & 21,283 & 6598 & 69.00 \\
\hline & BOD5 & 10,242 & 3029 & 71.00 \\
\hline & TSS & 7842 & 571 & 93.00 \\
\hline & TKN & 1910 & 1243 & 35.00 \\
\hline & $\mathrm{NH}_{4}^{+}$ & 1840 & 1182 & 38.00 \\
\hline & $\mathrm{TP}$ & 612 & 184 & 70.00 \\
\hline
\end{tabular}

elimination of $\mathrm{P}$ allows a greater agronomic application of the liquid fraction when land application of manure is based on P loads.

\section{Treatment of separated liquid}

\subsection{Nitrification-denitrification treatment}

Although most of the organic nitrogen is eliminated with the suspended solids, a significant amount of the total nitrogen continues to be in the ammonia soluble fraction, so that after the separation of solid-liquid fraction with polymers, the waste water must be treated to transform the ammonia when alternatives other than land application are required. One of the main transformations in this treatment is the conversion of ammonia into nitrate through microbial nitrification. There are two advanced processes to raise the concentration of nitrifying bacteria in the reaction tanks; polymer-immobilised nitrifying bacteria (PINBT) (Vanotti et al., 2001) and membrane bioreactors (BRM) (Martinez-Almela and Luna, 2002). The immobilisation process provides a very appropriate environment in order for the microorganisms to reach optimum efficiency. Ammonia nitrogen elimination rates from 915 to $990 \mathrm{mg}$ N/L-reactor/day have been obtained (after the solidliquid separation) and from $97 \%$ to $99 \%$ nitrification efficiency, without any inhibition in spite of the high rates of ammonia concentration (Vanotti et al., 2000). The membrane bioreactor is an advanced activated sludge system where membrane filtration replaces the clarifier. Thus, the system is operated with a very high concentration of microbial biomass in the reactors tanks resulting in an increased efficiency and treatment optimisation.

Biological denitrification processes can be combined with the nitrification reactor, in order to get the total removal of nitrogen. Given that the bacteria responsible for biological denitrification in anoxic conditions are heterotrophic, they require an appropriate source or organic carbon as an energy source. In the purification of the separated liquid fraction two basic types of organic carbon can be used: either an endogenous source contained in the waste water itself or an external source, such as methanol, unseparated liquid manure, etc. In the first case, the process leads to a pre-denitrification process which recycles one part of the nitrified effluent in an anoxic tank, and in the second case to a post-denitrification arrangement (Vanotti and Hunt, 2001; Vanotti et al., 2001).

\subsection{Phosphorus treatment}

There are three advanced processes available for the elimination of the remaining soluble P. The first system consists in parallel biological elimination of the $\mathrm{P}$ and $\mathrm{N}$, by means of a piston flow system with a two-phase anoxic reactor, followed by the anoxic-oxic reactor for reduction of $\mathrm{N}$; the second consists in the precipitation of the orthophosphate by means of inorganic salts

Table 2

Results of the physical-chemical analysis of the samples from the secondary module ( $\mathrm{N}$ and $\mathrm{P}$ )

\begin{tabular}{lccccc}
\hline Parameter & Unit & $\begin{array}{l}\text { Effluent after solids } \\
\text { separation }\end{array}$ & $\begin{array}{l}\text { Effluent after secondary } \\
\text { treatment }\end{array}$ & $\begin{array}{l}\text { \% Removal secondary } \\
\text { module }\end{array}$ & $\begin{array}{l}\text { \% Total removal by } \\
\text { system }\end{array}$ \\
\hline TSS & $\mathrm{mg} / 1$ & 543 & 20 & 96.32 & 99.84 \\
$\mathrm{COD}$ & $\mathrm{mg} / 1$ & 6040 & 161 & 97.33 & 99.30 \\
$\mathrm{BOD}_{5}$ & $\mathrm{mg} / 1$ & 5010 & 56 & 98.14 & 99.10 \\
$\mathrm{NH}_{4}^{+}$ & $\mathrm{mg} / 1$ & 69 & 1 & 95.82 & 97.71 \\
$\mathrm{TP}$ & $\mathrm{mg} / 1$ & 69 & & & 98.55 \\
\hline
\end{tabular}



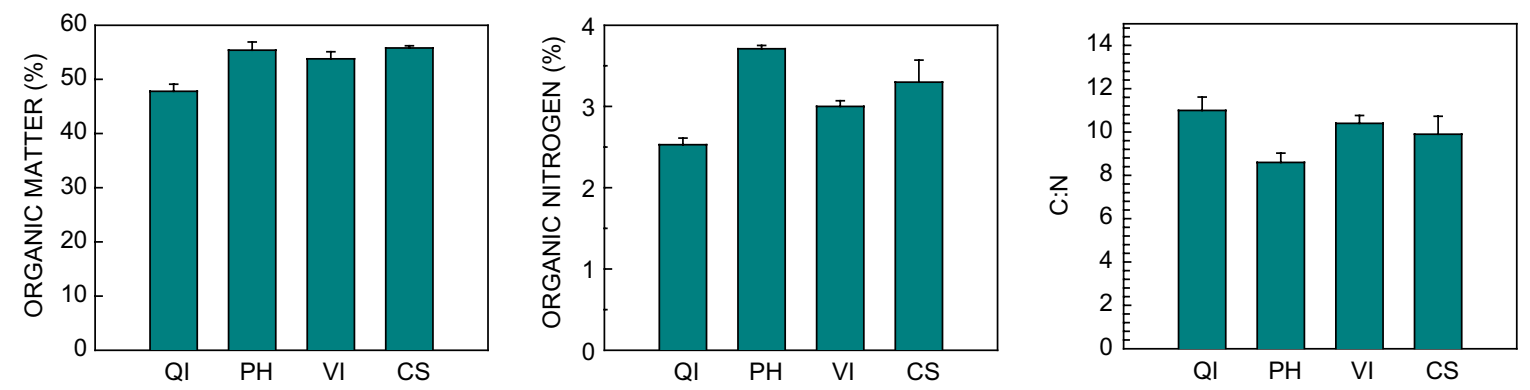

Fig. 3. Characteristics of compost produced by mixing separated swine manure solids with a variety of wastes. QI: Quercus ilex, PH: Pinus halepensis, VI: Vineyard, CS: Straw. Bars represent 1 standard deviation $(N=3)$.

$(\mathrm{Al}, \mathrm{Fe})$ and later transferring this sludge to the homogenisation tank to be treated again with the liquid-solid separation by means of polymer technology (Table 2). The third system goes by the USDA-ARS protocol, whose method consists in using hydrated lime and polymers to precipitate the phosphorus in the form of calcium phosphate. The phosphoric product contains around $23-29 \% \mathrm{P}_{2} \mathrm{O}_{5}$, and is dehydrated in $>50 \%$ of the solids using filtration bags, which makes the sub-product obtained easily marketable and transportable (Vanotti et al., 2003).

\section{Treatment and valorisation of separated solids}

\subsection{Agronomic and agro-forestry usage}

Liquid swine manure contains substantial amounts of essential nutrients for plant growth. Slurry can easily be valorized through composting with other organic residues. Although there is a long tradition of use of organic residues in forestry, their use for ecological restoration and soil conservation is still not fully developed. We conducted experiments to evaluate the potential for the use of pig slurry in ecological restoration and production of high quality growing media for the production of forest seedlings from the solid fraction separated with the Ecopurin technology (Martinez-Almela et al., 2002).

The composting was carried out in the open air in Spain between October 2000 and February 2001, and during this period the mixtures (1:3 ratio of manure and wastes, weight basis) were turned over twice a week. At the end of this time the compost produced from woody remains (QI, PH, VI) had an optimum appearance (in terms of sponginess, odor, color and humidity) while the PA compost still contained remains of not very decomposed straw and had a certain smell of ammonia. The granulometry of the compost was fine, complying with the standards on fertilizers and organic manures (Spanish order of 28th May 1998). The organic matter content was high (in all cases around 50\%) and thus also conforming to said regulation (Fig. 3). The nitrogen content varied from $2.5(\mathrm{QI})$ and $3.7(\mathrm{PH})$, also exceeding the $2 \%$ minimum regulated by legislation (Fig. 3 ). This is also the case for the $\mathrm{C}: \mathrm{N}$ ratio. This quotient, close to 10 in all the composts, underwent a considerable drop throughout the composting process.

The product can be added to lawns, seed beds, geofabrics, nursery substrates etc. as an economical material that complies with hygienic standards (Table 3). The composted solid fraction could also be used in other applications such as artificial substrate for production of plants at nurseries, organic substrate included in the composition of hydro-sowing, and organic additive incorporated in bedding, mulches and hydro-sowing supports.

\subsection{Power use, biogas and cogeneration}

Anaerobic digestion is a complex biological process by which, in the absence of oxygen, organic material is transformed into biogas or biological gas, formed mainly of methane and carbon anhydride. The percentage of methane in the biogas varies, according to the type of organic material digested and the process conditions, from a minimum of $50 \%$ up to roughly $80 \%$. The anaerobic alternative can be applied independently

Table 3

Microbiological quality compost analysis

\begin{tabular}{llll}
\hline Determination & Method & Units & Results \\
\hline Total coliforms & $\begin{array}{l}\text { Membrane filter; } \\
\text { Caldo Endo-MF }\end{array}$ & Ufc/100 ml & 0 \\
Fecal coliforms & $\begin{array}{l}\text { Membrane filter; } \\
\text { Agar m-FC }\end{array}$ & Ufc/100 ml & 0 \\
Salmonellae & $\begin{array}{l}\text { Agar Salmon. } \\
\text { XLD t } 37^{\circ} \mathrm{C}\end{array}$ & $\mathrm{Col} / 25 \mathrm{gr}$ & Absence \\
& $\begin{array}{l}t=24 \mathrm{~h} \\
\text { Aujeszky }\end{array}$ & & \\
IFD & - & Negative \\
Parvovirus sp. & IFD & - & Negative \\
BVD antigen & IFD & - & Negative \\
Rotavirus & IFD & - & Negative \\
Nematodes & Camera & - & Negative \\
& McMaster & & $<20$ \\
Escherichia coli & Coprocultive & Ufc/g & Absence \\
\hline
\end{tabular}



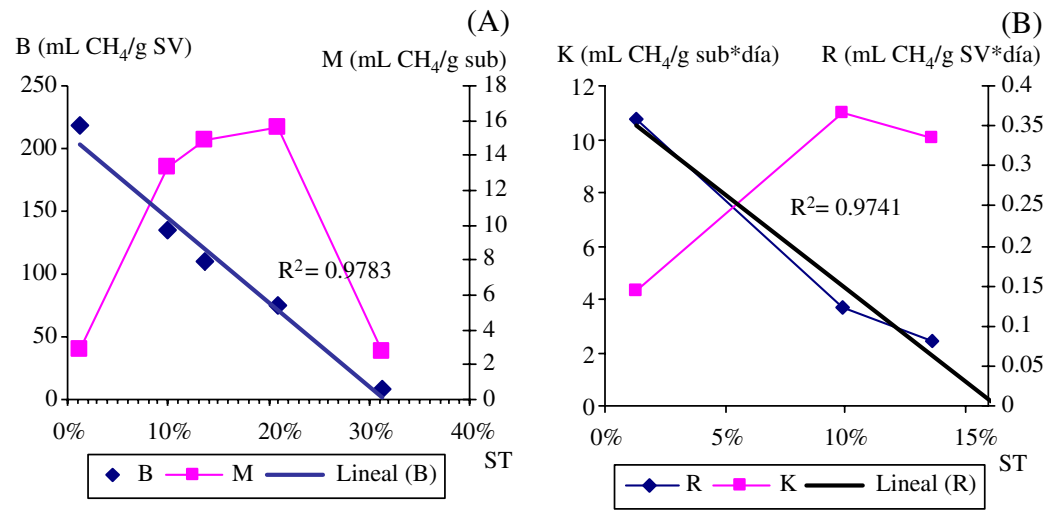

Fig. 4. (A) Relation between total solid contents and methane production in relation with volatile solids (B) and (M) substrate. (B) Estimate methane production rate respect to the initial SST content.

or along with the aerobic one, locating the Ecopurin main separation module either before the inlet to the primary anaerobic digester, in order to condense the dry and organic fraction contained in the manure or to the outlet of the secondary reactor, to treat the sludge and liquid line. With the implementation of the ionic transfer reactor (the SELCO-Ecopurin ${ }^{\circledR}$ main module) before the anaerobic digester one obtains sludge concentrations of between $12 \%$ and $20 \%$ instead of the $3-8 \%$ which would be meant by unconcentrated manure diluted by the processes of washing out the stables and other water addition in processing. This is one way to appreciate the content of organic material and gets a greater energy efficiency.

The heat power of the manure is set around $5000 \mathrm{Kcal} /$ $\mathrm{Nm}^{3}$ from the concentrated solid and, according to the type of farm, the production of methane ranges from 63 to $650 \mathrm{~m}^{3} / \mathrm{d}$ from 100 tons when 1000 tons of live weight are exceeded. The biogas produced is led to a cogeneration group, after desulphurisation, where it is transformed into thermoelectric energy, which produces considerable power savings for the farm itself. From the secondary digester, the sedimentation of the sludges and the extraction of the floating liquid takes place. The sludge line can be recirculated to the primary digester or removed in the SELCO-Ecopurin ${ }^{\circledR}$ main module for making compost. The liquid effluent is removed to the secondary or tertiary treatment module according to the needs, for its final purification until reaching the parameters required. This treatment is carried out either by another biological $\mathrm{N}$ module (Martinez-Almela et al., 2001b).

Anaerobic digestion of the solid fraction is an attractive option for its agronomic and energetic valorization. We studied the possible toxicity that PAMs residues may have over the anaerobic process. The optimum range of total solid concentration for a maximum gas production, as a function of PAMs concentration, has also been determined. The results showed that the anaerobic process is feasible for PAM rate application in the separation process of $120 \mathrm{ppm}$, which leads to a solid fraction with 13\% total solids (Fig. 4).

The accumulated production of methane increases as the content in total solids of the substrate increases, but the increase is not linear, being much greater at a lower level of solids. When studying the correlation of methane production in respect of initial SSV, one can observe a clear linear tendency towards reduction as the TSS content of the substrate rises (Fig. 4).

The most advantageous concentration of PAMs for optimizing the anaerobic digestion process must be such that this allows a concentration of total solids preferably under $10 \%$ to be obtained. As an initial approximation we could recommend a level of $8 \%$, but to confirm this further tests have to be carried out. In any event, and in spite of not proved the optimum level, the process is completely feasible for a concentration of $13 \%$, corresponding to a PAMs concentration of $120 \mathrm{ppm}$, without observing signs of inhibition, nor reduction of the volumetric production of methane, in respect of less concentrated treatments.

\section{References}

De la Torre, A., Martinez-Almela, J., Munoz. M.J., 2001. Estado del arte en las tecnologias de tratamiento, depuracion y valorizacion de los purines. In: Porci Monograph, No. 65, INIA, Spain, pp. 17-25.

Martinez-Almela, J., Barrera Marza, J., Lorenzo Navarro, M., 2001a. Production of energy and value-added products from manure. European Practice. In: Symposium Innovative processes to produce useful materials and energy from biosolids and animal manure. USEPA, Region $\mathrm{V}$ and Water Environment Federation. June 6-8, 2001. Ramada Hotel O'Hare, Chicago, Illinois.

Martinez-Almela, J., Campos, E., Almirall, M., Flotats, X., Barrera, J., 2001b. Digestion anaerobia de la fraccion solida de purines de cerdo, separada mediante el proceso SELCO-Ecopurin ${ }^{\circledR}$. Anaporc Cientifico 1, 41-51.

Martinez-Almela, J., Luna, A.M., 2002. El tratamiento de subproductos animales: Presente y futuro central de tratamiento de purines de la granja escuela de la facultad de veterinaria de la 
Universidad de Murcia. In Porci Monograph, No. 71, INIA, Spain, pp. $27-41$.

Martinez-Almela, J., Barrera Marza, J., Martinez Adsuara, V., 2002. Tecnologias sostenibles de SELCO MC. In Porci Monograph, No. 65, INIA, Spain, pp. 27-48.

Vanotti, M.B., Hunt, P.G., Rice, J.M., Humenik, F.J., 2000. Nitrifying high-strength wastewater. Industrial Wastewater (Sept./Oct.), 30-36.

Vanotti, M.B., Hunt, P.G., 2001. Treatment and sustainable management of manure and by-products: Problems and solutions in USA. In: Porci Monograph, No. 65, INIA, Spain, pp. 67-83.
Vanotti, M.B., Rice, J.M., Hunt, P.G., Humenik, F.J., Ellison, A.Q., Baird, C.A., Millner, P., Szogi, A.A., 2001. Evaluation of polymer solids separation, nitrification-denitrification and soluble phosphorus removal system for treating swine manure. In: Proceedings of International Symposium Addressing Animal Production and Environmental Issues, Raleigh, NC, p. 4.

Vanotti, M.B., Szogi, A.A., Hunt, P.G., 2003. Extraction of soluble phosphorus in a swine waste treatment system without lagoon. In: Proceedings of ISAAFPW 2003, October 11-14. ASAE, Raleigh, NC. 